\title{
Pengaruh Peregangan - Pemanasan dan Pemanasan - Peregangan Terhadap Kecepatan Lari 54,86 Meter (60 Yard)
}

\author{
Sulikan \\ Program Studi Pendidikan Jasmani Kesehatan Dan Rekreasi IKIP Budi Utomo \\ Jalan Simpang Arjuno 14B Malang \\ Sulikan_ms@yahoo.co.id
}

\begin{abstract}
Abstact: The purpose of the the research is to know the effectiveness of the influence of stretching-up and warming-up-stretching toward the velocity of 60 yard dash. Population used are the students (male) of IKIP Budi Utomo Malang S1 program especially the fifth semester. Here the writer takes 80 students as samples from 178 students ramdomly. The samples are divided into 4 gruops by matching them that each group consists of 20 students. The kind of research experiments is using the design of the study latin square. The experiments is done about 4 weeks, once a week. That uses four treatmen as follow : treatment $A, B, C$ and $D$. Each group is treated differently a week, so in 4 weeks all group will have same 4 kind of trentment. Tehnik collecting data obtained from pre-test and post-test that carried on four times. The analysis of data obtained Anava and " $t$ " test which use the value of significant $5 \%$ and $1 \%$. From the analysis of data above here the result: There is different influence that is very significant annong treatment $A, B, C, D$ in increasing the velocity of the 60 yard dash. Conclusion the influence of stretching-warning-up is more effective in increasing the velocity of 60 yard dash than the warming-up - stretching.
\end{abstract}

Keywords: peregangan-pernanasan, pemanasan-peregangan, kecepatan lari.

Dalam kehidupan modern saat ini, olahraga semakin mendapat perhatian, baik dari pihak pemerintah maupun dari masyarakat itu sendiri. Semua ini bertujuan untuk meningkatkan kesegaran jasmani rakyat agar pembangunan manusia Indonesia seutuhnya dan terealisasikan dan miliki oleh setiap individu rakyat Indonesia sesuai dengan kebutuhan masing - masing, agar dapat melakukan tugas masing - masing dengan baik. Karena dengan melakukan kegiatan olahraga dapat dikembangkan unsur - unsur kesegaran jasmani seperti muscle, strength, endurance, speed, agility, flexibility, balance, reaction timen, an coordination (Larson dan Yacom, 1951)

Disamping itu dapat pula dikembangkan factor - factor kejiwaan antara lain : disiplin, peraya diri, jujur, kerja sama, menghormati lawan dan kawan masih banyak lagi.

Sedangkan tujuan pendidikan olahraga adalah:

- Physical Fitnees (kesegaran jasmani)

- Motor Skill ( keterampilan motor)

- Knowledge (pengetahuan)

- Social Obyektive (pengetahuan)
- Keindahan tubuh dan etika (Seaton dkk, $1974: 7-9)$

- Oleh karena itu tiap - tiap cabang olahraga selalu mengambangkan unsur - unsur kesegaran jasmani seperti tersebut di atas.

Namun demikian ada sesuatu yang tidak dapat dipisahkan dari kegiatan olahraga yaitu cedera, yang sering dialami oleh para olahragawan. Macamnya tidak sedikit, ada cedera otot, ligamen, tendon, robek kulit, namun yang banyak terjadi ialah:

- Latihan yang berlebihan, adanya pemaksaan dari untuk berlatih di luar kemampuanya

- Cara berlatih yang salah : terlalu cepat ,eningkatkan intemsitas atau jumlah latihan.

- Kelainan struktural dalam tubuh : dapat memberikan stress tambahan pada otot, tendon, tulang, sendi, jaringan ikat dan ligament.

- Kurangnya Fleksibilitas : akibat latihan yang keras otot lebih rentan terhadap cedera.

- Ketidak seimbangan otot lebih kuat dari otot yang lain yang melakukan fingsi berlawanan. (G. Mirkin, H. Hoffman, 1978 : 27 - 30) 
Perlu dipahami, bahwa gerak yang paling penting dalam kehidupan sehari - hari adalah fleksi batang tubuh. Berpedoman dari uraian tersebut di atas, maka jelas dalam olahraga, tetapi juga penting untuk kehidupan sehari - hari atau dalam pekerjaan. (Sharkey, 1979) sedang untuk berlatih lentur togok ialah dengan stretching dan warming up serta latihan kelenturan. Untuk menghindari cedera dan sendi pada waktu melakukan aktifitas olahraga maka dapat dicegah dengan melakukan stretching dan warming up sebelum melakukanya. (Anderson, 1980 dan Jansen, 1984) berkurangnya cedera otot, warming up dapat menambah kecepatan dan ketepatan (Lawther, 1859 : 229) oleh karena itu dengan melakukan stretching dan Warming Up di samping meningkatkan lentur togok juga akan menambah kecepatan.

Stretching dan Warming up merupakan suatu proses untuk mengadakan perubahan-perubahan fisiologis dalam tubuh dan menyiapkan organ organ dalam menghadapi aktifitas tubuh yang lebih berat. Yang dimaksud dengan Warming Up dan stretching disini bukan melalui Massage, mandi air panas atau menggunakan tenaga listrik. Stretching dan warming up dimulai dengan gerakan - gerakan yang sederhana mudah dan ringan kemudian sedikit demi sedikit intensitas dipertinggi dan ruang gerak diperluas. Sehingga akan menambah keleluasaan gerak pada tubuh.

Banyak para pelatih, guru olahraga, atlit dan orang - orang yang terlibat dalam aktifitas olahraga umumnya dan kegiatan olahraga yang menjurus keprestasi khususnya kurang diperhatikan masalah stretching dan warming up untuk memlihara dan meningkatkan kelenturan tubuhnya. Salah satu unsur unsur meningkatkan kecepatan adalah lentur togok. Kecepatan tergantung dari beberapa factor yang mempengaruhinya, yaitu strength, waktu reaksi (reaksi time) dan fleksibilitas (kelenturan) (Willmore,1977). Stretching dan warming up dianggap tidak penting, apabila dilakukan latihan atretching dan warming up dalam waktu yang singkat dan tidak sungguh sungguh. Stretching dan warming up dianggap hanya membuang - buang waktu dan tenaga saja. Padahal kalau stretching dan warming-up dilakukan dengan sungguh-sungguh artinya gerakan dan bentuk latihan disesuaikan dengan cabang olahraga yang akan dilakukan akan membawa kondisi orang tersebut siap baik fisik maupun mental. (Suharno, 1978)
Banyak dalam aktifitas fisik terutama latihan dalam cabang olahraga, para pelatih atau atlit belum memahami benar metode latihan mana yang efektif dalam meningkatkan prestasi olahraga secara umum. Dan metode latihan untuk meningkatkan lentur togok dan kecepatan pada khususnya. Berdasarkan permasalahan tersebut diatas maka dalam rencana penelitian ini akan membandingkan efektifitas dua metode : yaitu strectching - warming up dan warming up - stretching terhadap lentur togok dan kecepatan lari 50 meter. Tujuan penelitian ingin membandingkan efektifitas pengaruh stretchingwarming-up dan warming-up - stretching.

\section{METODE}

Penelitian ini menggunakan jenis penelitian eksperimen lapangan yang dilakukan di lapanganSkodam Malang dengan menggunakan rancangan penelitian latin square. Subyek penelitian adalah mahasiswa putra FPOK IKIP Budi Utomo Malang yang mempunyai umur antara 18 - 22 tahun, jumlah orang coba 80 orang dari mahasiswa 178 orang yang dibagi menjadi 4 kelompok dengan cara matching dan masingmasing kelompok berjumlah 20 orang sebagai orang coba, dipilihnya tempat penelitian di FPOK IKIP Budi Utomo Malang, yaitu untuk memperoleh orang coba yang daerah tempat tinggalnya tidak terlalu berjauhan, transportasi tidak menjadi hambatan, sehingga masalah dropout sangat kecil. Diambilnya umur 18 - 22 tahun didasarkan pada pertimbangan bahwa pada usia tersebut sudah mencapai kematangan fisik. Teknik pengambilan subyek sebagai orang coba dengan cara random sampling untuk mendap peluang yang sama bagi semua subyek yang dipilih sabagai sample. Variabel terdiri dari : variabel bebas : (a) peregangan, (b) pemanasan, (c) peregangan-pemanasan.(d) pemanasanperegangan. Variabel terikat: Kecepatan lari 54, 86 meter ( 60 yard ). Variabel Kendali : Umur, Tinggi Badan, Berat Badan, Jenis Kelamin, Temperatur tubuh, Denyut Nadi.

Pelaksanaan penelitian : (1) penentuan dan pembagian kelompok orang coba, dalam pebelitian ini menggunakan 4 kelompok, dan setiapkelompok terdiridari20 orang coba dengan mendapat perlakuan yang sama. Perlakuannya adalah pada hari pertama minggu pertama semua orang coba mengikuti pre-test kemudian hasilnya diadakan metching untuk menentukan 
kelompok I, II, III,dan IV . (2) pelaksanaan pre-test : pengukuran berat badan, tinggi badan, denyut nadi, temperatur tubuh, pengambilan waktu lari cepat 54, 86 meter. Pengambilan waktu lari cepat 54, 86 meter dilakukan secara manual dengan menggunakan stopwatch. Waktu dicatat sampai 1/ 10 detik. 3. Eksperimen 1 : Untuk kelompok I setelah peregangan selama 20 menit, diteruskan dengan post test lari cepat 54, 86 meter. Hal ini dilakukan sekali dalam seminggu. Untuk kelompok II setelah melakukan pemanasan selama 20 menit diteruskan dengan post-tes lari cepat 54, 86 meter. Hal ini dilakukan sekali dalam seminggu. Untuk kelompok III setelah melakukan peregangan - pemanasan selama 20 menit diteruskan dengan post-test lari cepat 54,86 meter. Untuk kelompok IV setelah melakukan pemanasan - peregangan selama 20 menit diteruskan dengan post-test lari cepat 54,86 meter. Hal ini dilakukan sekali dalam seminggu. Eksperimen 2 : Untuk kelompok I setelah melakukan pemanasan selama 20 menit diteruskan post-test lari cepat 54, 86 meter.Hal ini dilakukan sekali dalam seminggu. Untuk kelompok II setelah melakukan peregangan - pemanasan diteruskan post - test lari cepat 54,86 meter diteruskan post - test lari cepat 54,86 meter. Hal ini dilakukan sekali dalam seminggu. Untuk kelompok III setelah melakukan pemanasan - peregangan diteruskan posttest lari cepat 54,86 meter. Hal ini dilakukan sekali dalam seminggu. Untuk Kelompok IV setelah melakukan peregangan selama 20 menit diteruskan post-test lari cepat 54,86 meter Hal ini dilakukan sekali dalam seminggu. Eksperimen 3 : Untuk kelompok I setelah melakukan peregangan - pemanasan diteruskan post-test lari cepat 54,86 mete Hal ini dilakukan sekali dalam seminggu. Untuk kelompok II setelah melakukan pemanasan - peregangan selama 20 menit diteruskan post-test lari cepat 54,86 meter. U Hal ini dilakukan sekali dalam seminggu ntuk kelompok III setelah melakukan peregangan selama 20 menit diteruskan post-test lari cepat 54, 86 meter. Untuk kelompok IV setelah melakukan pemanasan selama 20 menit diteruskan posttest lari cepat 54,86 meter. Hal ini dilakukan sekali dalam seminggu. Eksperiment 4. : Untuk kelompok I setelah melakukan pemanasan peregangan diteruskan post-test lari cepat 54,86 meter. Hal ini dilakukan sekali dalam seminggu. Untuk Kelompok II setelah melakukan peregangan selama 20 menit diteruskan post- test lari cepat 54,86 meter. Hal ini dilakukan sekali dalam seminggu. Untuk kelompok III setelah melakukan pemanasan selama 20 menit diteruskan post-test lari cepat 54,86 meter. Untuk kelompok IV setelah melakukan peregangan pemanasan selama 20 menit diteruskan post-test lari cepat 54,86 meter. Hal ini dilakukan sekali dalam seminggu.

Program masing-masing bentuk kegiatan adalah sebagai berikut: Peregangan, Pemanasan, Peregangan - pemanasan, pemanasan pereganganyangdilakukanolehsetiapkelompok dengan masing-masing kegiatan dilakukan selama 20 menit. Bentuk peregengannya meliputi : Stretching for the back, shoulders and arm ( 2 gerakan ), Stretching for lower back, hips, groin and hamstrings ( 2 gerakan ), Standing stretching for the legs and hips ( 6 gerakan), Stretching for the legs ( 1 gerakan ), Stretches for the back ( 1 gerakan ). Ada 12 macam gerakan dan masing-masing gerakan dilakukan 15 - 30 detik dengan metode peregangan statik. Bentuk pemanasannay meliputi : senam umum yaitu dimulai dengan jogging dilanjutkan dengan gerakan anggota badan bagian atas ke bawah dan diselingi dengan lari sprint beberapa meter.

Teknik pengunpulan data dengan melakukan pengukuran berat badan, tinggi badan, temperatur tubuh, denyut nadi dan pengetesan waktu lari cepat 54, 86 meter baik pre-test dengan taraf signifikansi $5 \%$ dan $1 \%$.

\section{HASIL DAN PEMBAHASAN}

Dari penelitian yang telah dilakukan dapat dikumpulkandata-data darikelompokI,II,IIIdan IV. N Data yang telah diklasifikasikan kemudian diolah menggunakan Anava rancangan latin square dan statistik uji " $t$ ". Hasilnya sebagai berikut : bahwa ringkasan Anava Rancangan Latin Square pada kegiatan "Peregangan( A ), pemanasan (B), peregegangan- pemanasan (C), dan pemanasan- peregangan( $D$ ) untuk peubah Lari Cepat 54, 86 meter ( 60 yard) disimpulkan ada perbedaan pengaruh yang sangat signifikan antar perlakuan yang berbeda-beda ( perlakuan A, B, C, D ) dalam melakukan lari cepat 54, 86 meter. Hasil dan pembahasan pada Eksperimen 1. Ringkas Anava antar perlakuan untuk Lari Cepat 54,86 meter, nipura perlakuan : $\mathrm{A}=80,3$, $\mathrm{B}=81,05, \mathrm{C}=89,45, \mathrm{D}=84,2$, kesimpulannya ada perbedaan pengaruhyang sangat signifikan antar perlakuan ( A, B, C, D ) dalam meningkatkan 
kecepatan Lari 54, 86 meter. Uji t menunjukkan bahwa nipura kecepatan lari 54,86 meter pada parlakuan A diperoleh skor $=80,3$, perlakuan B diperoleh skor $=81,05$, perbedaan skornya $=0,75$ dari uji t hasilnya perbedaanya tidak signifikan, kesimpulannya tidak ada perbedaan pengaruh antara perlakuan A dan B dalam meningkatkan kecepatan lari 54,86 meter.

Uji t nipura kecepatan lari 54,86 meter pada perlakuan A diperoleh skor $=80,3$, perlakuan C diperoleh skor $=89,45$, perbedaan skornya $=9,15$ dari uji thasilnya perbedaanya sangat signifikan, kesimpulanya bahwa perlakuan $\mathrm{C}$ lebih efektif untuk meningkatkan kecepatan lari 54,86 meter dibandingkan dengan perlakuan A.Uji t nipura kecepatan lari 54,86 meter pada perlakuan A dan D, nipura kecepatan lari 54,86 meter pada perlakuan A diperoleh skor $=80,3$, perlakuan D diperoleh skor $=84,2$, perbedaan skornya $=3,9$ dari uji $\mathrm{t}$ hasil perbedaannya sgnifikan, kesimpulannya bahwa perlakuan D lebih efektif dalam meningkatkan kecepatan lari 54,86 meter dibandingkan dengan perlakuan A.Uji t menunjukkan bahwa nipura kecepatan lari 54,86 meter pada parlakuan B diperoleh skor $=81,05$, perlakuan $C$ diperoleh skor $=89,45$, perbedaan skornya $=8,4$ dari uji $\mathrm{t}$ hasilnya perbedaanya sangat signifikan, kesimpulannya perlakuan C lebih efektif dalam meningkatkan kecepatan lari 54,86 meter dibandingkan dengan perlakuan B. Uji t nipura kecepatan lari 54,86 meter pada perlakuan B diperoleh skor $=81,05$, perlakuan D diperoleh skor $=84,2$, perbedaan skornya $=3,15$ dari uji t hasilnya perbedaanya tidak signifikan, kesimpulanya bahwa perlakuan B tidak ada perbedaan yang signifikan untuk meningkatkan kecepatan lari 54,86 meter dibandingkan dengan perlakuan D.Uji t nipura kecepatan lari 54,86 meter pada perlakuan $\mathrm{C}$ diperoleh skor $=89,45$ dan perlakuan $\mathrm{D}$ diperoleh skor $=84,2$ perbedaan skornya $=5,25$, dari uji $\mathrm{t}$ ada perbedaan yang sangat signifikan, kesimpulannya perlakuan C lebih efektif dalam meningkatkan kecepatan lari 54,86 meter dibandingakan engan pedrlakuan D.

Hasil dan Pembahasan Eksperiment 2. Ringkas Anava antar perlakuan untuk Lari Cepat 54,86 meter, nipura perlakuan : $\mathrm{A}=80,45$, $\mathrm{B}=81,2, \mathrm{C}=88,55, \mathrm{D}=84,35$, kesimpulannya ada perbedaan pengaruh yang sangat signifikan antar perlakuan ( A, B, C, D ) dalam meningkatkan kecepatan Lari 54, 86 meter. Uji t menunjukkan bahwa nipura kecepatan lari 54,86 meter pada parlakuan A diperoleh skor $=80,45$, perlakuan $\mathrm{B}$ diperoleh skor $=81,2$, perbedaan skornya $=0,75$ dari uji $\mathrm{t}$ hasilnya perbedaanya tidak signifikan, kesimpulannya tidak ada perbedaan pengaruh antara perlakuan A dan B dalam meningkatkan kecepatan lari 54,86 meter. Uji t nipura kecepatan lari 54,86 meter pada perlakuan A diperoleh skor $=80,45$, perlakuan C diperoleh skor $=88,55$, perbedaan skornya $=8,1$ dari uji thasilnya perbedaanya sangat signifikan, kesimpulanya bahwa perlakuan C lebih efektif untuk meningkatkan kecepatan lari 54,86 meter dibandingkan dengan perlakuan A.Uji t nipura kecepatan lari 54,86 meter pada perlakuan A dan D, nipura kecepatan lari 54,86 meter pada perlakuan A diperoleh skor $=80,45$, perlakuan D diperoleh skor $=84,35$, perbedaan skornya $=3,9$ dari uji $\mathrm{t}$ hasil perbedaannya sgnifikan, kesimpulannya bahwa perlakuan D lebih efektif dalam meningkatkan kecepatan lari 54,86 meter dibandingkan dengan perlakuan A.Uji t menunjukkan bahwa nipura kecepatan lari 54,86 meter pada parlakuan $\mathrm{B}$ diperoleh skor $=81,2$, perlakuan $\mathrm{C}$ diperoleh skor $=88,55$, perbedaan skornya $=7,35$ dari uji $\mathrm{t}$ hasilnya perbedaanya sangat signifikan, kesimpulannya perlakuan C lebih efektif dalam meningkatkan kecepatan lari 54,86 meter dibandingkan dengan perlakuan B. Uji t nipura kecepatan lari 54,86 meter pada perlakuan $\mathrm{B}$ diperoleh skor $=81,2$, perlakuan D diperoleh skor $=84,35$, perbedaan skornya $=3,15$ dari uji $t$ hasilnya perbedaanya sangat signifikan, kesimpulanya bahwa perlakuan D lebih efektif untuk meningkatkan kecepatan lari 54,86 meter dibandingkan dengan perlakuan B.Uji $t$ nipura kecepatan lari 54,86 meter pada perlakuan $\mathrm{C}$ diperoleh skor $=88,55$ dan perlakuan $\mathrm{D}$ diperoleh skor $=84,35$ perbedaan skornya $=4,2$, dari uji $\mathrm{t}$ ada perbedaan yang sangat signifikan, kesimpulannya perlakuan C lebih efektif dalam meningkatkan kecepatan lari 54,86 meter dibandingakan dengan perlakuan D.

Hasil dan Pembahasan Eksperiment 3. Ringkas Anava antar perlakuan untuk Lari Cepat 54,86 meter, nipura perlakuan : $\mathrm{A}=82,55, \mathrm{~B}=$ $81,05, \mathrm{C}=88,85, \mathrm{D}=84,65$, kesimpulannya ada perbedaan pengaruh yang sangat signifikan antar perlakuan ( A, B, C, D ) dalam meningkatkan kecepatan Lari 54, 86 meter. Uji t menunjukkan bahwa nipura kecepatan lari 54,86 meter pada parlakuan A diperoleh skor $=82,55$, perlakuan B diperoleh skor $=81,05$, perbedaan skornya 
$=1,5$ dari uji $\mathrm{t}$ hasilnya perbedaanya tidak signifikan, kesimpulannya tidak ada perbedaan pengaruh antara perlakuan A dan B dalam meningkatkan kecepatan lari 54,86 meter.Uji t nipura kecepatan lari 54,86 meter pada perlakuan A diperoleh skor $=82,55$, perlakuan $\mathrm{C}$ diperoleh skor $=88,85$, perbedaan skornya $=6,3$ dari uji $\mathrm{t}$ hasilnya perbedaanya sangat signifikan, kesimpulanya bahwa perlakuan $C$ lebih efektif untuk meningkatkan kecepatan lari 54,86 meter dibandingkan dengan perlakuan A.Uji t nipura kecepatan lari 54,86 meter pada perlakuan A dan $\mathrm{D}$, nipura kecepatan lari 54,86 meter pada perlakuan A diperoleh skor $=82,55$, perlakuan $\mathrm{D}$ diperoleh skor $=84,65$ perbedaan skornya $=$ 2,1 dari uji thasil perbedaannya tidak signifikan, kesimpulannya bahwa perlakuan D tidak ada perbedaan dalam meningkatkan kecepatan lari 54,86 meter dibandingkan dengan perlakuan A.Uji $t$ menunjukkan bahwa nipura kecepatan lari 54,86 meter pada parlakuan B diperoleh skor $=81,05$, perlakuan $\mathrm{C}$ diperoleh skor $=88,85$, perbedaan skornya $=7,8$ dari uji $\mathrm{t}$ hasilnya perbedaanya sangat signifikan, kesimpulannya perlakuan $\mathrm{C}$ lebih efektif dalam meningkatkan kecepatan lari 54,86 meter dibandingkan dengan perlakuan B. Uji t nipura kecepatan lari 54,86 meter pada perlakuan B diperoleh skor $=81,05$, perlakuan D diperoleh skor $=84,65$, perbedaan skornya $=3,6$ dari uji t hasilnya ada perbedaanya yang sangat signifikan, kesimpulanya bahwa perlakuan D lebih efektif untuk meningkatkan kecepatan lari 54,86 meter dibandingkan dengan perlakuan B. Uji t nipura kecepatan lari 54,86 meter pada perlakuan $\mathrm{C}$ diperoleh skor $=88,85$ dan perlakuan D diperoleh skor $=84,65$ perbedaan skornya $=4,2$, dari uji t ada perbedaan yang sangat signifikan, kesimpulannya perlakuan C lebih efektif dalam meningkatkan kecepatan lari 54,86 meter dibandingakan dengan perlakuan $\mathrm{D}$.

Hasil dan Pembahasan Eksperiment 3. Ringkas Anava antar perlakuan untuk Lari Cepat 54,86 meter, nipura perlakuan : $\mathrm{A}=80,3$, $\mathrm{B}=79,53, \mathrm{C}=89,0, \mathrm{D}=84,95$, kesimpulannya ada perbedaan pengaruh yang sangat signifikan antar perlakuan ( A, B, C, D ) dalam meningkatkan kecepatan Lari 54, 86 meter. Uji t menunjukkan bahwa nipura kecepatan lari 54,86 meter pada parlakuan A diperoleh skor $=80,3$, perlakuan $\mathrm{B}$ diperoleh skor $=79,53$, perbedaan skornya $=0,75$ dari uji $\mathrm{t}$ hasilnya perbedaanya tidak signifikan, kesimpulannya tidak ada perbedaan pengaruh antara perlakuan A dan B dalam meningkatkan kecepatan lari 54,86 meter. Uji t nipura kecepatan lari 54,86 meter pada perlakuan A diperoleh skor $=80,3$, perlakuan $\mathrm{C}$ diperoleh skor $=89,0$, perbedaan skornya $=8,7$ dari uji thasilnya perbedaanya sangat signifikan, kesimpulanya bahwa perlakuan C lebih efektif untuk meningkatkan kecepatan lari 54,86 meter dibandingkan dengan perlakuan A.Uji t nipura kecepatan lari 54,86 meter pada perlakuan A dan D, nipura kecepatan lari 54,86 meter pada perlakuan A diperoleh skor $=80,3$, perlakuan D diperoleh skor $=84,95$ perbedaan skornya $=4,65$ dari uji $\mathrm{t}$ hasil perbedaannya sangat signifikan, kesimpulannya bahwa perlakuan D dalam meningkatkan kecepatan lari 54,86 meter dibandingkan dengan perlakuan A. Uji t menunjukkan bahwa nipura kecepatan lari 54,86 meter pada parlakuan B diperoleh skor $=80,3$, perlakuan $C$ diperoleh skor $=89,0$, perbedaan skornya $=9,45$ dari uji $\mathrm{t}$ hasilnya perbedaanya sangat signifikan, kesimpulannya perlakuan C lebih efektif dalam meningkatkan kecepatan lari 54,86 meter dibandingkan dengan perlakuan B. Uji t nipura kecepatan lari 54,86 meter pada perlakuan B diperoleh skor $=80,3$, perlakuan D diperoleh skor $=84,95$, perbedaan skornya $=5,4$ dari uji t hasilnya ada perbedaanya yang sangat signifikan, kesimpulanya bahwa perlakuan D lebih efektif untuk meningkatkan kecepatan lari 54,86 meter dibandingkan dengan perlakuan B.

Uji t nipura kecepatan lari 54,86 meter pada perlakuan C diperoleh skor $=89,0$ dan perlakuan D diperoleh skor $=84,95$ perbedaan skornya $=4,05$, dari uji $\mathrm{t}$ ada perbedaan yang signifikan, kesimpulannya perlakuan $C$ lebih efektif dalam meningkatkan kecepatan lari 54,86 meter dibandingakan dengan perlakuan D. Dari hasil analisa dengan menggunakan Anava rancangan latin square untuk kecepatan lari pada perlakuan A, B, C, dan, D dalam eksperimen 1, 2, 3 dan 4 ( post-test). Diperoleh hasil yang menunjukkan ada beda pengaruh yang sangat signifikan antar perlakuan A, B, C dan D dalam meningkatkan kecepatan lari 54,86 meter, yaitu Fratio $=128,8327$ $>\mathrm{Ft} 1 \%=3,87(\mathrm{P}<0,01)$. Hal ini sesuai dengan pernyataan yang terdapat dalam hipotesa dan Tinjauan Kepustakaan, bahwa peregangan dan pemanasan dapat meningkatkan kecepatan, kekuatan dan ketahanan tubuh, meningkatkan kekleluasan gerak, dan mengurangi terjadinya cidera.

Dari hasil uji t pada eksperimen 1, 2, 3 dan 4 dengan perlakuan A, B, C, dan D menunjukkan 
bahwa perlakuan $\mathrm{C}$ menghasilkan prestasi yang lebih baik dibandingkan dengan perlakukan $\mathrm{A}$, B, dan D. Dengan hasil nipura kecepatan lari 54,86 meter pada perlakuan $\mathrm{C}=88,9625$, nipura perlakuan $\mathrm{D}=84,5375$, nipura perlakuan $\mathrm{A}$ $=80,9$, dan nipura perlakuan $\mathrm{B}=80,4625$. Hal ini menunjukkan bahwa nipura perlakuan $C$ lebih besar perlakuan D, A, dan B. Dengan demikian bahwa perlakuan $C$ lebih baik dalam meningkatkan kecepatan lari 54,86 meter dibandingkan dengan perlakuan D, A,dan B. Ringkasan uji " $\mathrm{t}$ " antar perlakuan untuk kecepatan lari 54,86 meter pada eksperimen 1,2 3, dan 4. Untuk membahas bahwa masingmasing perlakuan dapat meningkatkan kecepatan lari 54,86 meter maka perlu penjelasan sebagai berikut: ( 1 ) bahwa peregangan dapat meningkatkan kecepatan lari 54,86 meter karena : (a ) dengan melakukan peregangan dengan benar terutama peragangan statik akan mengurangi ketegangan otot dan membuat tubuh merasa lebih rilek. (b) dengan melakukan peregangan membantu koordinasi untuk memberikan gerakan yang lebih bebas dan lebih mudah.(c) dengan melakukan peregangan menintgkatkan keleluasaan gerak. (d) dengan melakukan peregangan dapat mendikteksi adanya otot atau sendi yang nyeri dan mencegah terjadinya cedera otot. ( e) dengan melalukan peregangan meningkatkan sirkulasi darah. (f) dengan melakukan peregangan memelihara kesiapan tubuh untuk aktivitas yang lebih berat. ( 2 ) pemanasan dapat meningkatkan kecepatan lari 54,86 meter, karena : (a )engan melakukan pemanasan aktivitas dan reaksi metabolisme meningkat. (b)dengan melakukan pemanasan terjadi peningkatan penggunaan oksigen yang menyebabkan sirkulasi darah ke otot bertambah cepat. (c) dengan melakukan pemenasan kecepatan dan kekuatan kontraksi serta penghantaran impuls lebih cepat. (d) dengan melakukan pemanasan denyut nadi meningkat sesuai dengan peningkatan temperatur tubuh. ( e ) dengan melalukakn pemanasan membantu melebarkan pembuluh darah otot dan secara bertahap dapat meregangkan tendon serta ligamen, sehingga memperkecil kemungkinan terjadinya cedera. ( 3 ) peregangan- pemanasan dapat meningkatkan kecepatan lari 54,86 meter karena : (a) dengan melakukan peregangan kemudian dilanjutkan dengan pemanasan, maka otot-otot yang kaku menjadi lebih fleksibel sehingga gerakan-gerakan dalam melakukan pemanasan menjadi lebih mudah dan lebih bebas. ( $b$ ) dengan melakukan peregangan lebih dahulu sebelum aktivitas yang lebih berat, akan menyiapkan kondisi fisik yang lebih siap dalam melakukan pemanasan sehingga peningkatan suhu tubuh menjadi maksimal. (c) dengan peningkatan suhu tubuh yang maksimal dalam batas-batas pemnasan, maka kekentalan darah menurun lebih cepat, sehingga peredaran darah menjadi lebih lancar, aktivitas enzim-enzim oksidatif meningkat. (d) dengan meningkatnya unsur-unsur tersebut diatas, maka kecepatan dan kekuatan kontraksi otot menjadi bertambah besar, sehingga kecepatan berlari juga menjadi lebih cepat. (e) dengan demikian bahwa dari gerakan peregangan ke pemanasan merupakan gerakan progresif. ( 4 ) pemanasan-peregangan dapat meningkatkan kecepatan lari 54,86 meter, karena pemenasan-peregangan tidak sama dengan peregangan-pemanasan, karena kalau peregangan - pemanasan menuju kearah progresif, yaitu warming-up secara umum, sedangkan pemanasan-peregangan menuju kearah warming-down/ colling down, sehingga peranannya dalam penampilan tidak maksimal.

\section{KESIMPULAN DAN SARAN}

Dari hasil analisis dan kajian kepustakaan serta praktek langsung melalui penelitian eksperimen lapangan maka dengan melakukan peregangan statik sebelum beraktivitas dengan benar dapat meningkatkan kecepatan lari 54,86 meter ( 60 yard ), demikian juga jika melaku melakukan pemanasan sebelum beraktivitas disamping meningkat kecepatan lari, mencegah terjadinya cedera pada sendi, ligamen dan cedera otot serta memperluas keleluasaan gerak sendi.

Peregangan kemudian dilanjutkan dengan melakukan pemanasan maka otot-otot yang kaku akan menjadi lebih fleksibel sehingga gerakan-gerakan dalam melakukan pemanasan akan lebih mudah dan lebih bebas, menyiapkan kondisi fisik untuk aktivitas yang lebih berat. Dengan melakukan peregangan kemudian dilanjutkan dengan pemanasan hasilnya akan lebih baik manfaatnya dibandingkan hanya melakukan peregangan saja atau pemanasan saja, serta jangan sampai terbalik cara melakukannya karena peregangan kemudian dilanjutkan dengan pemanasan tidak sama dengan jika melakukan pemanasan dulu baru melakukan 
peregangan. Kalau pemanasan dulu kemudian melakukan peregangan maka sama dengan melakukan warming-down/ coolling-down. Jadi yang benar dalam beraktivitas olahraga sebaiknya lakukan peregangan kemudian dilanjutkan pemanasan antara 10 - 15 menit.

Berdasarkan kesimpulan di atas, hendaknya para guru pendidikan jasmani memahami arti pentingnya melakukan peregangan dan pemanasan sebelum mengajar praktek olahraga di sekolah untuk menghindari terjadinya cedn pemnera pada para siswanya, bagi pelatih dan pembina olahraga hendaknya jangan terlalu fokus pada ketrampilan atlitnya saja tapi juga harus menjaga keselamatan atlitnya. Semoga artikel ini ada manfaatnya semua yang terlibat dalam aktivitas olahraga.

\section{DAFTAR RUJUKAN}

Allen, P. D. dan Harnak. J.K. 1974. Maesurement And Evaluation In Physical Education. USA, Burgess Publishing Company.

Anderson. 1980. Stretching, Shelter publication Canad, Ltd.

Astrad P.O. 1956.Human physical Fitness With Spesial Reference to Sex and Age. Physical Rev. 36: 307 - 335

Bompa, T. O. 1983. Theory And Methodology of Training, Kendal/Hunt Publising Company, Dubuge, Iowa.

Bosco J.S. dan William F.G 1983.Measurement and Evaluation in Physical Education,
Fitnes and Sport. New Jersey..

Bruce R. E., dan Eva J. L., 1987. Cronic and acute fleksibility Of Men And Women Using Three Defferent. RQ. For. Ex : 59 (3) pp. 222 - 227, Riice University.

David, M. H. and Edward T. H. 1989. Effect of static stretching and Warming Up On Prevention Of Delayed - Onset Muscle Sorenes. R,Q. For. Ex. And spt: 60 (4), Pp.357 - 360, University Of Tenesse. Knoxville.

De Vrioes, H, A. 1986. Physiology of Exercise For Physical Education And Atletics. 3rd, William Brown Co. Dubuque, Iowa, Cited by Harsono, MSc.

DeVries, H.A.1960. Elektromiograpihic Observation Of The Effect Of statics

Stretching Upon Muscle Distress, R.Q : 32 (4) Long Beach 4 California.

De Vries H.A. 1961. Evaluation Of Static Stretching Procedure For Improvement Of Fleksibility. R.Q. : 33 (2) pp. 222 - 229.

Don Cash, S., Irene A. C., Howard C. L., and Liovd L. M. 1974. Physical Education Handbook, Prentice - Hall, INC. Englewood, America, pp. 7 - 8.

Don , R. K., Joseph J. G., dan Robert, E. J. 1980. Measurement and Evaluation For Physical educators. Brown Company Publising, Dubuque. Iowa,pp. 18 - 19.

Edward, L. F.1979. Sport Physiology, Sounder College, Philadelpia, pp. 206. 
8 | Sulikan, Pengaruh Peregangan-Pemanasan dan Pemanasan-Peregangan ... 